Article

\title{
Yeast Nanometric Scale Oscillations Highlights Fibronectin Induced Changes in C. albicans
}

\author{
Anne-Céline Kohler 1,*(i), Leonardo Venturelli ${ }^{1}{ }^{\circledR}$, Abhilash Kannan ${ }^{2}$, Dominique Sanglard ${ }^{2}$, \\ Giovanni Dietler ${ }^{1,3}$, Ronnie Willaert ${ }^{3,4,5}$ iD and Sandor Kasas 1,2,6 \\ 1 Laboratoire de Physique de la Matière Vivante, EPFL, 1015 Lausanne, Switzerland; \\ leonardo.venturelli@epfl.ch (L.V.); giovanni.dietler@epfl.ch (G.D.); sandor.kasas@epfl.ch (S.K.) \\ 2 Institute of Microbiology, Lausanne University Hospital, CH-1011 Lausanne, Switzerland; \\ Abhilash.Kannan@chuv.ch (A.K.); Dominique.Sanglard@chuv.ch (D.S.) \\ 3 International Joint Research Group VUB-EPFL NanoBiotechnology \& NanoMedicine (NANO), \\ Vrije Universiteit Brussel, 1050 Brussels, Belgium; Ronnie.Willaert@vub.be \\ 4 Research Group Structural Biology Brussels, Alliance Research Group VUB-UGent \\ NanoMicrobiology (NAMI), 1050 Ixelles, Belgium \\ 5 Department Bioscience Engineering, University Antwerp, 2000 Antwerp, Belgium; \\ Ronnie.Willaert@uantwerpen.be \\ 6 Plateforme de Morphologie UFAM, CUMRL, University of Lausanne, 1015 Lausanne, Switzerland \\ * Correspondence: anne-celine.kohler@epfl.ch; Tel.: +41-216930464
}

Received: 18 December 2019; Accepted: 19 February 2020; Published: 21 February 2020

\begin{abstract}
Yeast resistance to antifungal drugs is a major public health issue. Fungal adhesion onto the host mucosal surface is still a partially unknown phenomenon that is modulated by several actors among which fibronectin plays an important role. Targeting the yeast adhesion onto the mucosal surface could lead to potentially highly efficient treatments. In this work, we explored the effect of fibronectin on the nanomotion pattern of different Candida albicans strains by atomic force microscopy (AFM)-based nanomotion detection and correlated the cellular oscillations to the yeast adhesion onto epithelial cells. Preliminary results demonstrate that strongly adhering strains reduce their nanomotion activity upon fibronectin exposure whereas low adhering Candida remain unaffected. These results open novel avenues to explore cellular reactions upon exposure to stimulating agents and possibly to monitor in a rapid and simple manner adhesive properties of C. albicans.
\end{abstract}

Keywords: Candida albicans; adhesion; fibronectin; nanomotion; atomic force microscope (AFM)

\section{Introduction}

Yeast biotechnology is a recent field where nanotechniques are used to manipulate and analyze yeast cells and cell constituents at the nanoscale [1]. Among the nanotechniques, AFM-related approaches played a major role in unveiling morphological, mechanical and biochemical properties of yeast [2-4]. Recently, our team demonstrated that living cells attached onto a soft cantilever induce nanometric scale oscillations (referred to as nanomotion) that stop as soon as the organism dies [5]. Commercially available atomic force microscopes (AFM) or dedicated devices easily detect these oscillations. Nanomotion detection has been applied to numerous biological samples such as proteins, single organelles, and a plethora of living cells such as prokaryotes (bacteria) and eukaryotes (fungal, vegetal and mammalian cells) [6]. The most straightforward application of the technique is the ultra-rapid antibiotic sensitivity test (AST). AST can be performed within an hour as compared to long-lasting traditional AST methods, which depend on the replication rate of the bacteria [7-9]. The test consists in attaching the organism of interest onto an AFM cantilever and monitoring its oscillations as a function of time upon addition of antibiotics in the analysis chamber. It is worth noting 
that the nanometric scale oscillations do not only reflect the living or death state of the organisms but also its activity $[5,10]$.

Fungal infections are a major public health issue nowadays; it is estimated that every year fungi infect about 1.2 billion people [11]. C. albicans is a common fungal pathogen that belongs to the human microbiome of healthy individuals [12]. This commensal relationship is a complex interplay of candidial and human factors. However, impairment of the host immunity or the normal host microbiota can lead to C. albicans infection (candidiasis) [13]. C. albicans is the predominant cause of virtually all types of candidiasis [14]. The first step of the infection is the adhesion of C. albicans onto the host. This step is an essential determinant of pathogenesis, as it allows C. albicans to attach to host cells and to form biofilms or to disseminate in the host blood vessels. The biofilm increases yeast cell resistance to antifungal therapeutics and protects it from the host immune system [15]. C. albicans has developed multiple ways to colonize and infect host cells and tissues. One such mechanism is the specific ligand-receptor interaction through a whole range of adhesins displayed on the yeast cell wall [16-18]. These cell wall proteins are capable of recognizing protein ligands [16], glycolipids [19-22] and carbohydrates [23-29] on the host cells. Fibronectin is an important protein ligand of the host extracellular matrix (ECM) that plays an essential role in C. albicans adhesion [30]. Furthermore, targeting fibronectin has shown to alter C. albicans biofilm formation [31]. Therefore, a better understanding of the yeast-fibronectin interaction could lead to novel therapeutic options to fight candidiasis.

In this work, we applied nanomotion analysis to monitor the oscillatory activity of $C$. albicans upon exposure to fibronectin. We used an AFM-based nanomotion detector to follow the evolution of cellular oscillations in the absence and the presence of fibronectin on strongly and poorly adherent $C$. albicans cells. Interestingly, these two isolates reacted very differently to the interaction with fibronectin. These preliminary results demonstrate the potential of nanomotion analysis to monitor ligand-receptor interactions in a label free manner.

\section{Materials and Methods}

\subsection{Yeast Strains}

The C. albicans isolate 101 and CEC 3675 were kindly provided by Salomé Leibundgut and Christophe D'Enfert laboratories [32], respectively. The yeasts were cultured in yeast-extracted peptone-dextrose (YPD) medium (1\% m/v yeast extract (Difco Laboratories, Fisher Scientific, Hampton, $\mathrm{NH}, \mathrm{USA}$ ), $2 \% \mathrm{~m} / \mathrm{v}$ peptone (Difco Laboratories, Fisher Scientific, Hampton, NH, USA) and $2 \% \mathrm{~m} / \mathrm{v}$ glucose (Sigma, St. Louis, MI, USA)) overnight at $30{ }^{\circ} \mathrm{C}$ with shaking (160 rpm).

\subsection{Experimental Procedures}

Rectangular tipless cantilevers (qp-CONT, NanoandMore GmbH, Wetzlar, Germany), with a nominal spring constant of $0.1 \mathrm{~N} / \mathrm{m}$ and an average resonant peak in liquids of $8 \mathrm{kHz}$, were coated with $2 \mathrm{mg} / \mathrm{mL}$ of concanavalin A (Con A) (Sigma, St. Louis, MI, USA) for $30 \mathrm{~min}$ at room temperature. After removing the excess of Con A, the yeast cells were placed in contact with the cantilever for $1 \mathrm{~h}$ at room temperature to allow them to attach to its surface. Poorly attached C. albicans cells were removed by washing gently with YPD medium. Finally, the $C$. albicans covered cantilever was inserted into the analysis chamber containing $2 \mathrm{~mL}$ of filtered ( $0.2 \mu \mathrm{m}$ syringe filter, Merck Millipore, Burlington, MA, USA) YPD medium. The measurements were performed at room temperature in YPD medium and in YPD medium containing $25 \mu \mathrm{g} / \mathrm{mL}$ of fibronectin (Sigma, USA). Fibronectin was directly added inside the chip reservoir. For the experiments performed with antifungals, caspofungin (Sigma, USA) was diluted in the YPD present in the analysis chamber to reach a final concentration of $100 \mu \mathrm{g} / \mathrm{mL}$. 


\subsection{Nanomotion Detector}

The cantilever oscillations were collected in real time using an in-house developed nanomotion detection device. The system relies on a laser-based signal transduction as typically used in commercial AFMs. A typical experiment lasted for $2 \mathrm{~h}$. The control experiments were carried out for at least $4 \mathrm{~h}$.

\subsection{Software and Nanomotion Analysis}

The cantilever oscillations were recorded and saved at $20 \mathrm{kHz}$ using a USB-4431 DAQ card (National Instruments, Austin, TX, USA). The data acquisition program was developed in LabView. A dedicated Python program was used to process the recorded data and to display the deflection of the cantilever as a function of time. The software first removes the low frequency cantilever displacement signal by calculating a first order fit of the raw signal (deflection of the cantilever) by taking 20 seconds-long window frames. The obtained fit is then subtracted from the raw signal to remove thermally induced cantilever deflection. The thermal drift essentially occurs at the beginning of the experiment and during the fluid exchange procedures. The thermal drift free signal is further processed to obtain its variance in 10 seconds-window frames.

\subsection{Viability Assay}

Cells were placed inside a commercially available microfluidic chip (Ibidi, Planegg, Germany), and stained with calcofluor white (Sigma, USA), according to the manufacturer's instructions. To detect dead cells, propidium iodide (PI, Sigma, USA) was added to the YPD medium and the fluorescence of the yeast cells was recorded using an Axiovert microscope (Zeiss, Oberkochen, Germany).

\subsection{Adhesion Assay}

Adherence of C. albicans to TR146 cells was measured using the protocols previously described [33,34] with slight modifications (Figure S1). TR146 cells grown as monolayers in 6-well plates were incubated with $100 \mathrm{C}$. albicans cells for $20 \mathrm{~min}$ at $37^{\circ} \mathrm{C}$. The supernatant was carefully removed and spread on YPD agar plates to determine the number of non-adherent fungal cells. The adherent fungal cells that were left behind in the 6-well plates were rinsed with PBS and were overlaid with melted Wort agar at $40{ }^{\circ} \mathrm{C}$. The plates were incubated at $30{ }^{\circ} \mathrm{C}$ for $36 \mathrm{~h}$ to count the colonies. Adherence was determined as the ratio of the number of colonies grown on Wort agar to the number of colonies grown on Wort agar and the number of colonies grown from the culture supernatant.

\subsection{Statistical Analysis}

Statistical analysis of nanomotion experiments were performed with the Python package Scipy. We performed the non-parametric Mann-Whitney $U$ test for the three independent replicates. We used standard student $t$-test to process the adhesion assay on three independent replicates using the Graphpad Prism software.

\section{Results}

To assess a putative differential reaction of strongly and weakly interacting C. albicans to fibronectin, we quantified the adhesion of two different isolates, 101 and CEC3675, on oral keratinocytes (TR 146). As shown in Figure 1 isolate 101 was measured to have a significantly higher adhesion compared to isolate CEC3675.

To investigate the C. albicans-fibronectin interaction we used an in house nanomotion detector depicted in Figure 2A. The set up consists in an analysis chamber filled with liquid (in our case YPD) containing the cantilever to which yeast cells are attached (Figure 2B). The cantilever oscillations were recorded (Figure 2C) and processed to display the signal variance as a function of time (Figure 2D). 


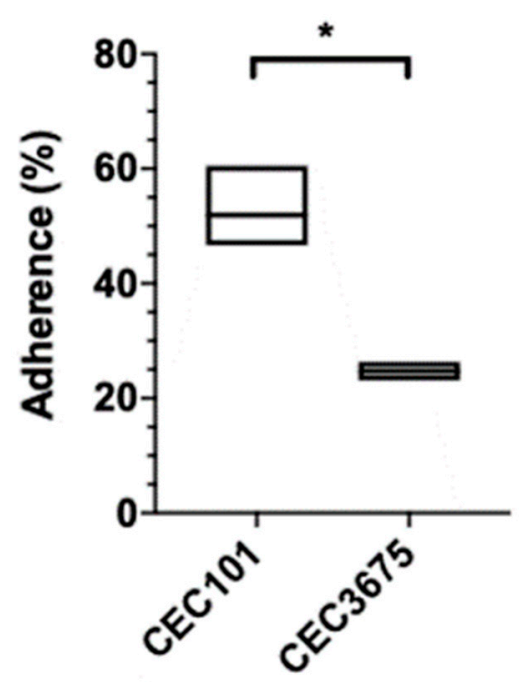

Figure 1. C. albicans isolates 101 and CEC3675 adhere differently to oral keratinocytes. Percentage of adherence of both isolates. Statistical analysis $(n=3)$ was done using standard t-test. The asterisk represents $p<0.05$.

A.
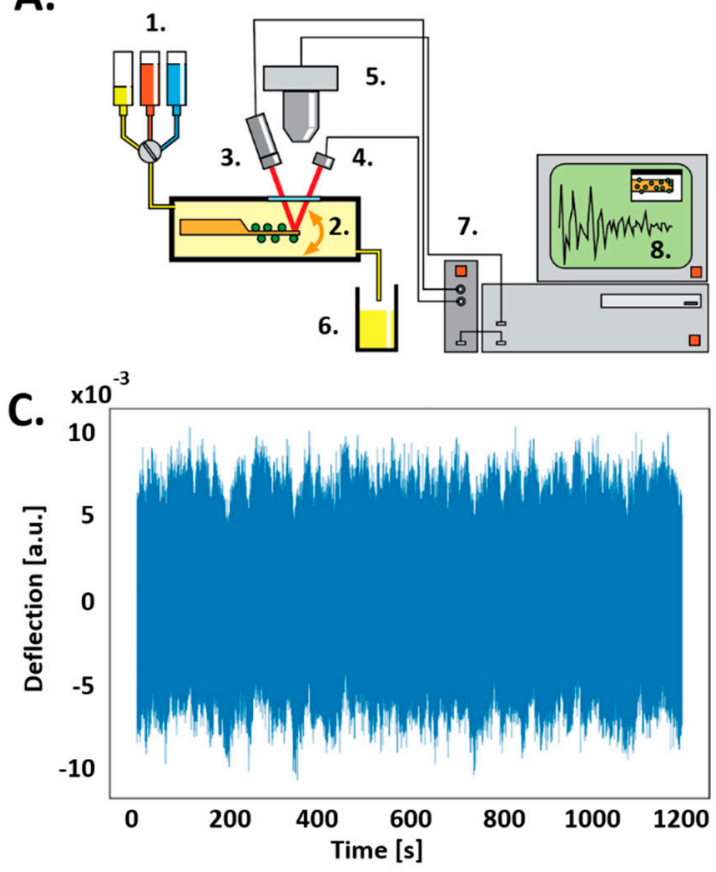

B.

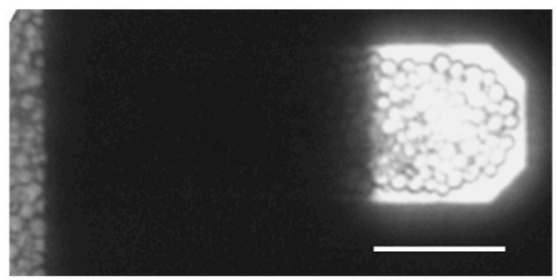

D.

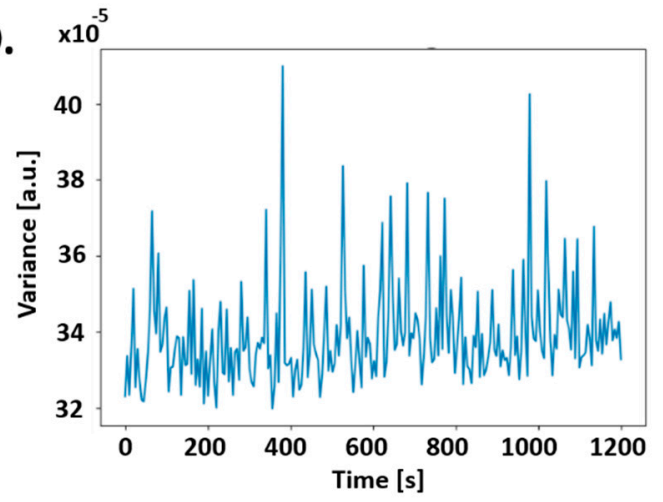

Figure 2. Nano-mechanical sensor system. (A) Representative image of a cantilever with attached $C$ albicans cells. Scale bar $40 \mu \mathrm{m}$. (B) Schematic of the experimental system and data collection. (1) Liquids to be injected into the analysis chamber. In our case YPD, YPD containing fibronectin, and YPD containing caspofungin. (2) Analysis chamber with the AFM cantilever and C. albicans attached onto its surface (green circles). (3) Super luminescent diode. (4) Four-segment photodiode. (5) Optical microscopy with camera. (6) Liquid waste. (7) In-house dedicated electronics and National Instruments data acquisition card. (8) Desktop computer. (C). The collected raw data are processed; and (D). analyzed using the variance of the signal.

Using this system, we monitored the nanomotion pattern of C. albicans isolates 101 and CEC3675 in the absence and presence of fibronectin (Figure 3). Before addition of fibronectin, both isolates behaved similarly (Figure 3B). However, in the presence of fibronectin, nanomotion activity (variance) of isolate 101 drastically decreased (from $0.9 \pm 0.5$ to $0.3 \pm 0.1$ ) (Figure 3). In contrast, isolate CEC3675 
did not present a significant decrease. To confirm that the drop of signal was not due to a change in the temperature, nor convective currents that can appear upon addition of a liquid in the analysis chamber, we performed control experiments, simultaneously, with another nanomotion detector. These experiments consisted in injecting the same quantity of medium, instead of fibronectin, into the analysis chamber. The obtained results showed no significant difference in the nanomotion pattern, for both isolates, upon addition of YPD media (Figure S2). Additionally, we assessed the number of cells present on the cantilever before and after the experiment to determine if the reduced signal was caused by cells being detached from the cantilever. The analysis of the images taken by the optical microscope located above the nanomotion detector (as depicted in the schematic in Figure 2A) confirmed that no cells detached from the cantilever throughout the experiments (Figure S3).
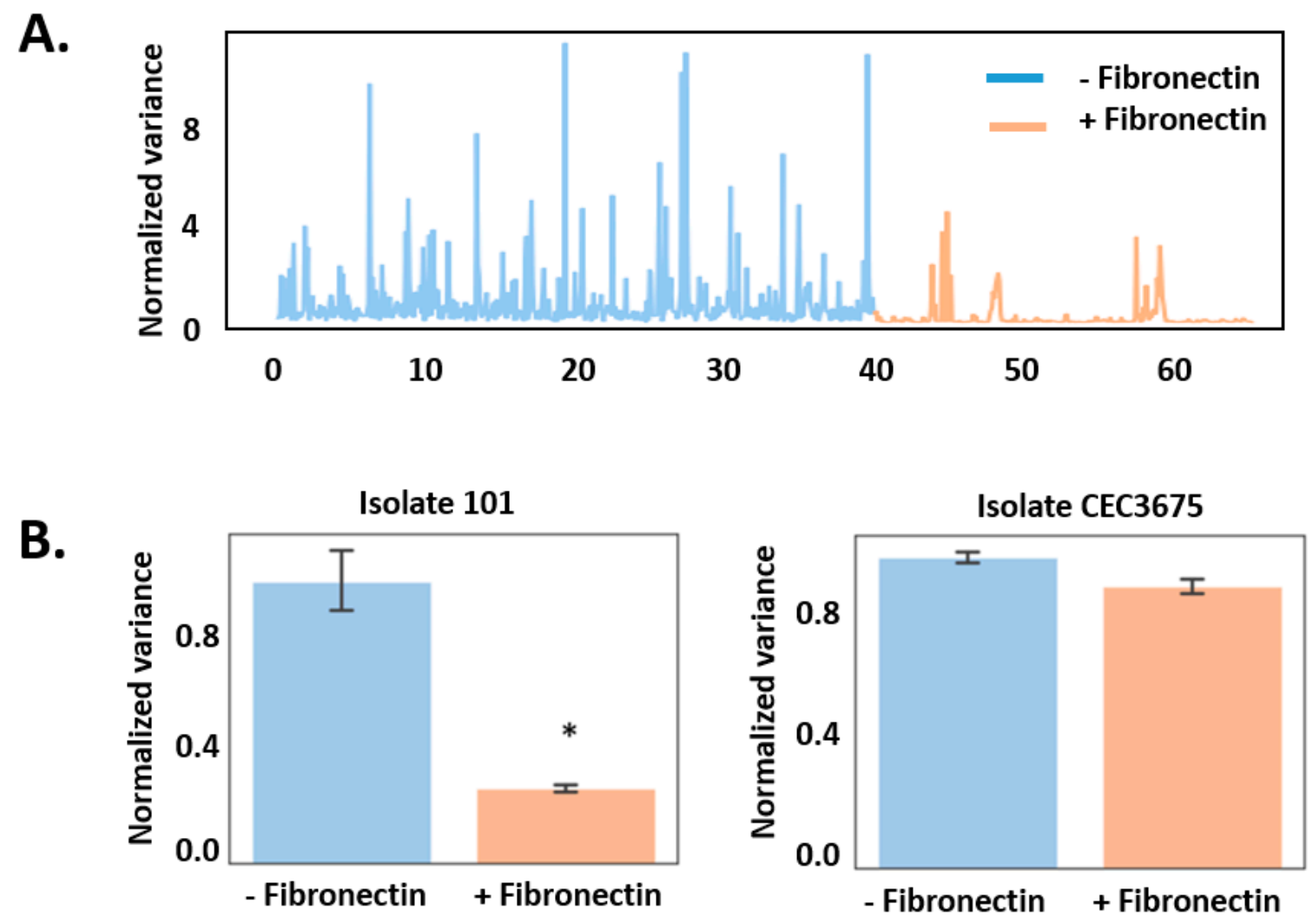

Figure 3. C. albicans isolate 101 and CEC 3675 react differently to fibronectin. (A). Representative graph of the normalized variance of isolate 101 in YPD (blue) and in YPD with fibronectin (orange). The decrease of the normalized variance is clearly visible between the two conditions. (B). The mean of the normalized variance (experiment in triplicate) represented as a bar plot for isolate 101 compared to isolate CEC 3675. Error bars are the confidence of intervals. Statistical analyses were done using Mann-Whitney $\mathrm{U}$ test, the asterisk represents $p<0.05$.

To further exclude another cause of the decrease of the nanomotion signal for isolate 101, such as premature cell death, we monitored C. albicans viability by nanomotion and fluorescence microscopy in the absence and presence of fibronectin. Eventually the cells were killed by the antifungal caspofungin. As shown in Figure 3A, the variance of the nanomotion signal drastically dropped after the drug injection. The fluorescent viability test did not show any effect of fibronectin on the cellular viability as it can be noticed in Figure 4B. Similarly, fibronectin also did not have any effect on the viability of isolate CEC3675 (Figure S4). 


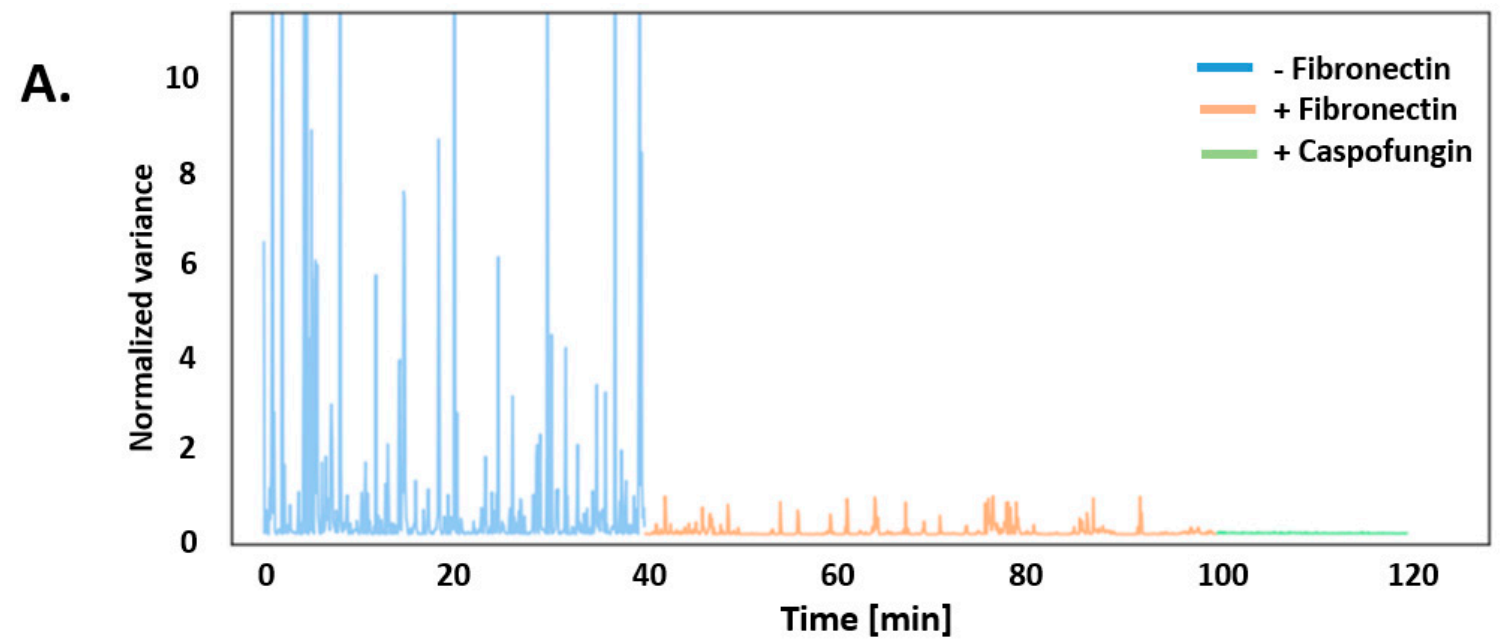

B.

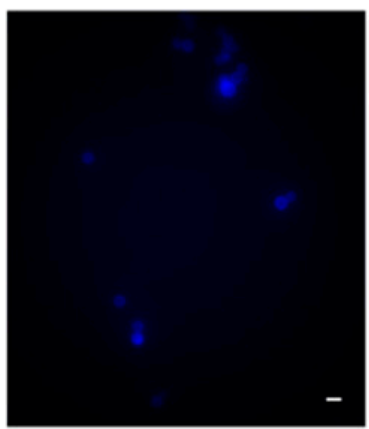

- Fibronectin

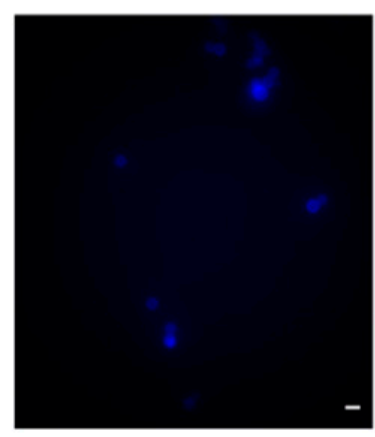

+ Fibronectin

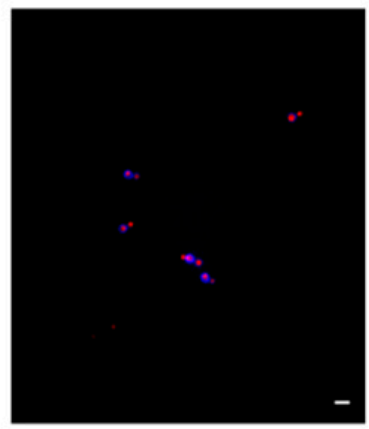

+ Caspofungin

Figure 4. Viability assay of C. albicans. (A). Nanomotion signal of C. albicans isolate 101 in the absence (blue curve) and presence of fibronectin (orange curve), and after killing the cells by the antifungal caspofungin (green curve). (B). Representative fluorescence images of C. albicans isolate 101 in the absence (left panel) and presence of fibronectin (middle panel), and after killing (right panel). Scale bar $5 \mu \mathrm{m}$.

\section{Discussion}

C. albicans infection is a multistep process, consisting in the binding of C. albicans on epithelial cells. In a first adhesion step, the C. albicans adhesins of the agglutinin-like sequence (Als) family bind to ECM proteins of the host such as fibronectin [35,36], laminin and collagen. The attachment of the yeast cell to the host is followed by the penetration and transmigration of hypha into host cells, which then leads to vascular dissemination as soon the hypha reaches blood vessels. In this study we only explored the interaction of fibronectin with the yeast form. Adhesins playing a role in the planktonic C. albicans adhesion are the Als family members Als1 [27] and Als5 [37], Eap1 [38-40], Csh1 (cell surface hydrophobicity) [41,42], Ihd1 [43,44] and members of the SAP family [45-47]. It has been shown that Als1, Als5, and Csh1 interacts with fibronectin; Sap9 and Sap10 can interact with the ECM proteins collagen and vimentin. It has not yet been demonstrated that fibronectin is a ligand for Sap9/10, Eap1 and Ihd1.

Here, we used nanomotion detection to monitor the oscillation pattern of planktonic C. albicans cells upon exposure to fibronectin. Two different clinical isolates that showed a different adhesive phenotype, were used. The isolate 101 adhered significantly stronger to the host epithelial cells compared to isolate CEC3675. Nanomotion experiments showed that fibronectin affects isolate 101 significantly more than CEC 3675. This drop of the nanomotion signal indicates a modification of the cellular activity upon fibronectin-C. albicans interaction. These results suggest that the initiation of adhesion related signaling in the yeast cell upon fibronectin attachment is mediated by the interaction with adhesins. Potential adhesion candidates that have been shown to interact with fibronectin are 
Als1, Als3 and Csh1. The complete elucidation of the molecular mechanisms involved in the process are still unclear and deserve further research. We plan to investigate which specific adhesin(s) is (are) involved in the observed activity reduction. Additionally, the effect of other ligands such as laminin, collagen IV, fibrinogen and gelatin [28,48-50] should also be investigated.

This work demonstrated the ability of nanomotion detection to monitor in real time and in a label-free manner cellular activity changes induced by interacting ligands. Activity changes induced by increasing glucose concentration were observed for Escherichia coli in a previous study [5]. This technique opens novel avenues to detect cellular activation or inhibition induced by ligand-receptor interactions.

Supplementary Materials: The following are available online at http:/www.mdpi.com/2311-5637/6/1/28/s1, Figure S1: Schematic representation of the adhesion assay protocol, Figure S2: Effect of the injection of YPD medium in the analysis chamber, Figure S3: Density of yeast cells on the cantilever, Figure S4: Viability assay of isolate CEC3675.

Author Contributions: Conceptualization, A.-C.K.; methodology, A.-C.K. and L.V.; software, A.-C.K.; validation, A.-C.K., L.V. and A.K.; formal analysis A.-C.K., investigation, A.-C.K., L.V., A.K.; resources, S.K., writing-original draft preparation, S.K. and A.-C.K.; writing-review and editing all the authors; visualization, A.-C.K., A.K.; supervision, A.-C.K., S.K.; project administration, S.K., G.D.; funding acquisition, S.K., G.D., D.S., R.W. All authors have read and agreed to the published version of the manuscript.

Funding: This research was funded by Schweizerischer Nationalfonds zur Förderung der Wissenschaftlichen Forschung 200021-144321, CRSII5_173863 and 407240_167137, the Gebert Rüf Stiftung GRS-024/14, NASA NNH16ZDA001N-CLDTCH, EPFL and ESA PRODEX project Yeast Bioreactor.

Acknowledgments: The authors thanks C. d'Enfert for providing the Candida albicans strains and S. Leibundgut for highly constructive discussions. The technical assistance of Danielle Brandalise is acknowledged. The Belgian Federal Science Policy Office (Belspo) and the European Space Agency (ESA) PRODEX program supported this work. The Research Council of the Vrije Universiteit Brussel (Belgium) and the University of Ghent (Belgium) are acknowledged to support the Alliance Research Group VUB-UGent NanoMicrobiology (NAMI), and the International Joint Research Group (IJRG) VUB-EPFL BioNanotechnology \& NanoMedicine (NANO).

Conflicts of Interest: The authors declare no conflict of interest.

\section{References}

1. Willaert, R.; Kasas, S.; Devreese, B.; Dietler, G. Yeast Nanobiotechnology. Fermentation 2016, 2, 18. [CrossRef]

2. Formosa-Dague, C.; Duval, R.E.; Dague, E. Cell biology of microbes and pharmacology of antimicrobial drugs explored by Atomic Force Microscopy. Semin. Cell Dev. Biol. 2018, 73, 165-176. [CrossRef]

3. Alsteens, D.; Müller, D.J.; Dufrêne, Y.F. Multiparametric Atomic Force Microscopy Imaging of Biomolecular and Cellular Systems. Acc. Chem. Res. 2017, 50, 924-931. [CrossRef] [PubMed]

4. Kasas, S.; Stupar, P.; Dietler, G. AFM contribution to unveil pro- and eukaryotic cell mechanical properties. Semin. Cell Dev. Biol. 2018, 73, 177-187. [CrossRef] [PubMed]

5. Longo, G.; Alonso-Sarduy, L.; Rio, L.M.; Bizzini, A.; Trampuz, A.; Notz, J.; Dietler, G.; Kasas, S. Rapid detection of bacterial resistance to antibiotics using AFM cantilevers as nanomechanical sensors. Nat. Nanotechnol. 2013, 8, 522-526. [CrossRef]

6. Kohler, A.C.; Venturelli, L.; Longo, G.; Dietler, G.; Kasas, S. Nanomotion detection based on atomic force microscopy cantilevers. Cell Surf. 2019, 5, 100021. [CrossRef]

7. Villalba, M.I.; Stupar, P.; Chomicki, W.; Bertacchi, M.; Dietler, G.; Arnal, L.; Vela, M.E.; Yantorno, O.; Kasas, S. Nanomotion Detection Method for Testing Antibiotic Resistance and Susceptibility of Slow-Growing Bacteria. Small 2018, 14, 1702671. [CrossRef]

8. Stupar, P.; Opota, O.; Longo, G.; Prod'hom, G.; Dietler, G.; Greub, G.; Kasas, S. Nanomechanical sensor applied to blood culture pellets: A fast approach to determine the antibiotic susceptibility against agents of bloodstream infections. Clin. Microbiol. Infect. 2017, 23, 400-405. [CrossRef]

9. Mustazzolu, A.; Venturelli, L.; Dinarelli, S.; Brown, K.; Floto, R.A.; Dietler, G.; Fattorini, L.; Kasas, S.; Girasole, M.; Longo, G. A rapid unravelling of mycobacterial activity and of their susceptibility to antibiotics. Antimicrob. Agents Chemother. 2019, 63, 02194-18. [CrossRef]

10. Kasas, S.; Ruggeri, F.S.; Benadiba, C.; Maillard, C.; Stupar, P.; Tournu, H.; Dietler, G.; Longo, G. Detecting nanoscale vibrations as signature of life. Proc. Natl. Acad. Sci. USA 2015, 112, 378-381. [CrossRef] 
11. Brown, G.D.; Denning, D.W.; Levitz, S.M. Tackling human fungal infections. Science 2012, 336, 647. [CrossRef] [PubMed]

12. Ghannoum, M.A.; Jurevic, R.J.; Mukherjee, P.K.; Cui, F.; Sikaroodi, M.; Naqvi, A.; Gillevet, P.M. Characterization of the Oral Fungal Microbiome (Mycobiome) in Healthy Individuals. PLoS Pathog. 2010, 6, e1000713. [CrossRef] [PubMed]

13. Rupp, S. Interactions of the fungal pathogen Candida albicans with the host. Future Microbiol. 2007, 2, 141-151. [CrossRef] [PubMed]

14. Filler, S.G.; Sheppard, D.C. Fungal Invasion of Normally Non-Phagocytic Host Cells. PLoS Pathog. 2006, 2, e129. [CrossRef] [PubMed]

15. Nobile, C.J.; Johnson, A.D. Candida albicans Biofilms and Human Disease. Annu. Rev. Microbiol. 2015, 69, 71-92. [CrossRef] [PubMed]

16. Chaffin, W.L.; López-Ribot, J.L.; Casanova, M.; Gozalbo, D.; Martínez, J.P. Cell Wall and Secreted Proteins ofCandida albicans: Identification, Function, and Expression. Microbiol. Mol. Biol. Rev. 1998, 62, 130-180. [CrossRef]

17. Sundstrom, P. Adhesion in Candida spp. Cell. Microbiol. 2002, 4, 461-469. [CrossRef]

18. Filler, S.G. Candida-host cell receptor-ligand interactions. Curr. Opin. Microbiol. 2006, 9, 333-339. [CrossRef]

19. Ghannoum, M.A.; Burns, G.R.; Abu Elteen, K.; Radwan, S.S. Experimental evidence for the role of lipids in adherence of Candida spp. to human buccal epithelial cells. Infect. Immun. 1986, 54, 189-193. [CrossRef]

20. Jimenez-Lucho, V.; Ginsburg, V.; Krivan, H.C. Cryptococcus neoformans, Candida albicans, and other fungi bind specifically to the glycosphingolipid lactosylceramide (Gal beta 1-4Glc beta 1-1Cer), a possible adhesion receptor for yeasts. Infect. Immun. 1990, 58, 2085-2090. [CrossRef]

21. Yu, L.; Lee, K.K.; Sheth, H.B.; Lane-Bell, P.; Srivastava, G.; Hindsgaul, O.; Paranchych, W.; Hodges, R.S.; Irvin, R.T. Fimbria-mediated adherence of Candida albicans to glycosphingolipid receptors on human buccal epithelial cells. Infect. Immun. 1994, 62, 2843-2848. [CrossRef] [PubMed]

22. Cameron, B.J.; Douglas, L.J. Blood group glycolipids as epithelial cell receptors for Candida albicans. Infect. Immun. 1996, 64, 891-896. [CrossRef] [PubMed]

23. Sandin, R.L.; Rogers, A.L.; Patterson, R.J.; Beneke, E.S. Evidence for mannose-mediated adherence of Candida albicans to human buccal cells in vitro. Infect. Immun. 1982, 35, 79-85. [CrossRef] [PubMed]

24. Critchley, I.A.; Douglas, L.J. Role of glycosides as epithelial cell receptors for Candida albicans. J. Gen. Microbiol. 1987, 133, 637-643. [CrossRef]

25. Macura, A.B.; Tondyra, E. Influence of some carbohydrates and concanavalin A on the adherence of Candida albicans in vitro to buccal epithelial cells. Zentralbl. Bakteriol. 1989, 272, 196-201. [CrossRef]

26. Brassart, D.; Woltz, A.; Golliard, M.; Neeser, J.R. In vitro inhibition of adhesion of Candida albicans clinical isolates to human buccal epithelial cells by Fuc alpha 1-2Gal beta-bearing complex carbohydrates. Infect. Immun. 1991, 59, 1605-1613. [CrossRef]

27. Donohue, D.S.; Ielasi, F.S.; Goossens, K.V.Y.; Willaert, R.G. The N-terminal part of Als1 protein from Candida albicans specifically binds fucose-containing glycans. Mol. Microbiol. 2011, 80, 1667-1679. [CrossRef]

28. Ielasi, F.S.; Alioscha-Perez, M.; Donohue, D.; Claes, S.; Sahli, H.; Schols, D.; Willaert, R.G. Lectin-glycan interaction network-based identification of host receptors of microbial pathogenic adhesins. MBio 2016, 7. [CrossRef]

29. Everest-Dass, A.V.; Kolarich, D.; Pascovici, D.; Packer, N.H. Blood group antigen expression is involved in C. albicans interaction with buccal epithelial cells. Glycoconj. J. 2017, 34, 31-50. [CrossRef] [PubMed]

30. Calderone, R.A.; Scheld, W.M. Role of fibronectin in the pathogenesis of candidal infections. Rev. Infect. Dis. 1987, 9, S400-S403. [CrossRef]

31. Nett, J.E.; Cabezas-Olcoz, J.; Marchillo, K.; Mosher, D.F.; Andes, D.R. Targeting fibronectin to disrupt in vivo Candida albicans biofilms. Antimicrob. Agents Chemother. 2016, 60, 3152-3155. [CrossRef] [PubMed]

32. Ropars, J.; Maufrais, C.; Diogo, D.; Marcet-Houben, M.; Perin, A.; Sertour, N.; Mosca, K.; Permal, E.; Laval, G.; Bouchier, C.; et al. Gene flow contributes to diversification of the major fungal pathogen Candida albicans. Nat. Commun. 2018, 9, 2253. [CrossRef] [PubMed]

33. Murciano, C.; Moyes, D.L.; Runglall, M.; Tobouti, P.; Islam, A.; Hoyer, L.L.; Naglik, J.R. Evaluation of the Role of Candida albicans Agglutinin-Like Sequence (Als) Proteins in Human Oral Epithelial Cell Interactions. PLoS ONE 2012, 7, e33362. [CrossRef] [PubMed] 
34. Schönherr, F.A.; Sparber, F.; Kirchner, F.R.; Guiducci, E.; Trautwein-Weidner, K.; Gladiator, A.; Sertour, N.; Hetzel, U.; Le, G.T.T.; Pavelka, N.; et al. The intraspecies diversity of C. albicans triggers qualitatively and temporally distinct host responses that determine the balance between commensalism and pathogenicity. Mucosal Immunol. 2017, 10, 1335-1350. [CrossRef] [PubMed]

35. Skerl, K.G.; Calderone, R.A.; Segal, E.; Sreevalsan, T.; Scheld, W.M. In vitro binding of Candida albicans yeast cells to human fibronectin. Can. J. Microbiol. 1984, 30, 221-227. [CrossRef] [PubMed]

36. Douglas, L.J. Adhesin-Receptor interactions in the attachment of Candida albicans to host epithelial cells. Can. J. Bot. 1995, 73, 1147-1153. [CrossRef]

37. Alsteens, D.; Beaussart, A.; Derclaye, S.; El-Kirat-Chatel, S.; Park, H.R.; Lipke, P.N.; Dufrêne, Y.F. Single-cell force spectroscopy of Als-mediated fungal adhesion. Anal. Methods 2013, 5, 3657-3662. [CrossRef] [PubMed]

38. Li, F.; Palecek, S.P. EAP1, a Candida albicans Gene Involved in Binding Human Epithelial Cells. Eukaryot. Cell 2003, 2, 1266-1273. [CrossRef] [PubMed]

39. Li, F.; Svarovsky, M.J.; Karlsson, A.J.; Wagner, J.P.; Marchillo, K.; Oshel, P.; Andes, D.; Palecek, S.P. Eap1p, an adhesin that mediates Candida albicans biofilm formation in vitro and in vivo. Eukaryot. Cell 2007, 6, 931-939. [CrossRef] [PubMed]

40. Li, F.; Palecek, S.P. Distinct domains of the Candida albicans adhesin EAP1 p mediate cell-cell and cell-substrate interactions. Microbiology 2008, 154, 1193-1203. [CrossRef]

41. Hooshdaran, M.Z.; Barker, K.S.; Hilliard, G.M.; Kusch, H.; Morschhäuser, J.; Rogers, P.D. Proteomic analysis of azole resistance in Candida albicans clinical isolates. Antimicrob. Agents Chemother. 2004, 48, 2733-2735. [CrossRef] [PubMed]

42. Singleton, D.R.; Fidel, P.L.; Wozniak, K.L.; Hazen, K.C. Contribution of cell surface hydrophobicity protein 1 (Csh1p) to virulence of hydrophobic Candida albicans serotype A cells. FEMS Microbiol. Lett. 2005, 244, 373-377. [CrossRef] [PubMed]

43. de Groot, P.W.J.; Hellingwerf, K.J.; Klis, F.M. Genome-wide identification of fungal GPI proteins. Yeast 2003, 20, 781-796. [CrossRef] [PubMed]

44. McCall, A.D.; Pathirana, R.U.; Prabhakar, A.; Cullen, P.J.; Edgerton, M. Candida albicans biofilm development is governed by cooperative attachment and adhesion maintenance proteins. NPJ Biofilms Microbiomes 2019, 5, 21. [CrossRef]

45. Watts, H.; Cheah, F.S.; Hube, B.; Sanglard, D.; Gow, N.A. Altered adherence in strains of Candida albicans harbouring null mutations in secreted aspartic proteinase genes. FEMS Microbiol. Lett. 1998, 159, 129-135. [CrossRef]

46. Naglik, J.R.; Challacombe, S.J.; Hube, B. Candida albicans Secreted Aspartyl Proteinases in Virulence and Pathogenesis. Microbiol. Mol. Biol. Rev. 2003, 67, 400-428. [CrossRef]

47. Kumar, R.; Breindel, C.; Saraswat, D.; Cullen, P.J.; Edgerton, M. Candida albicans Sap6 amyloid regions function in cellular aggregation and zinc binding, and contribute to zinc acquisition. Sci. Rep. 2017, 7, 1-15. [CrossRef]

48. Klotz, S.A.; Gaur, N.K.; Lake, D.F.; Chan, V.; Rauceo, J.; Lipke, P.N. Degenerate peptide recognition by Candida albicans adhesins Als5p and Als1p. Infect. Immun. 2004, 72, 2029-2034. [CrossRef]

49. Sheppard, D.C.; Yeaman, M.R.; Welch, W.H.; Phan, Q.T.; Fu, Y.; Ibrahim, A.S.; Filler, S.G.; Zhang, M.; Waring, A.J.; Edwards, J.E. Functional and structural diversity in the Als protein family of Candida albicans. J. Biol. Chem. 2004, 279, 30480-30489. [CrossRef]

50. Argimón, S.; Wishart, J.A.; Leng, R.; Macaskill, S.; Mavor, A.; Alexandris, T.; Nicholls, S.; Knight, A.W.; Enjalbert, B.; Walmsley, R.; et al. Developmental regulation of an adhesin gene during cellular morphogenesis in the fungal pathogen Candida albicans. Eukaryot. Cell 2007, 6, 682-692. [CrossRef]

(C) 2020 by the authors. Licensee MDPI, Basel, Switzerland. This article is an open access article distributed under the terms and conditions of the Creative Commons Attribution (CC BY) license (http://creativecommons.org/licenses/by/4.0/). 